\title{
Effect of cats tail leaves extract (acalypha hispida burm. f.) on wound healing (traumatic ulcer) of wistar male rat oral mucosa (rattus norvegicus)
}

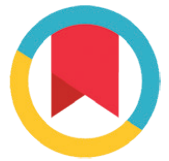

CrossMark

\author{
Sumintarti, ${ }^{*}$ Jessica Juliana
}

\begin{abstract}
Objective: To determine the effect of cats tail leaves extract (Acalypha hispida Burm. F.) on wound healing ofWistar male rat mucosa (Rattus norvegicus) as the result of this experimental which obtained later can be used as a reference in dentistry to develop cats tail leaves as an alternative medicine in traumatic ulcer treatment.

Material and Methods: This is an experimental research with post-test only control group design. The experimental subject were 24 Wistar male rat divided into four treatment groups, including a $50 \%$ A. hispida leaves group, a $75 \%$ A. hispida leaves group, a $100 \%$ A. hispida leaves group, and povidone iodine control group. All rat in every group were given the treatment and the decrease of wound diameter were measured for 8 days then the data were processed using SPSS program.
\end{abstract}

\section{processed using SPSS program.}

Results: The average of traumatic wound diameter on 8th day is $0.33 \pm 0.41 \mathrm{~mm}$ for $50 \%$ A. hispida leaves group, $0.50 \pm 0.45 \mathrm{~mm}$ for $75 \%$ A. hispida leaves group, $0.25 \pm 0.42 \mathrm{~mm}$ for $100 \% \mathrm{~A}$. hispida leaves group, and $1.17 \pm 0.61 \mathrm{~mm}$ for control group. Based on Friedman test and Wilcoxon test, the result shows significant difference on wound diameter change in every treatment group. Conclusion: Cats tail leaves extract (acalypha hispida burm. F.) with concentration of $50 \%, 75 \%$ and $100 \%$ have the effect of wound healing on traumatic injury of white rat oral mucosa (rattus novergicus) but there is no significant difference in effectivenessbetween every concentration.
Departement of Oral Medicine, Faculty of Dentistry, Hasanuddin University, Makassar, Indonesia
*Correspondence to: Sumintarti, Departement of Oral Medicine, Faculty of Dentistry, Hasanuddin University, Makassar, Indonesia JJThioritz@yahoo.com

Received: 3 January 2020 Revised: 5 February 2020 Accepted: 28 March 2020 Available Online: 1 April 2020

Keywords: Healing, wound, Corner lips, Sargassum Sp.

Cite this Article: Sumintarti, Juliana J. 2020. Effect of cats tail leaves extract (acalypha hispida burm. f.) on wound healing (traumatic ulcer) of wistar male rat oral mucosa (rattus norvegicus). Journal of Dentomaxillofacial Science 5(1): 56-61. D0I: 10.15562/jdmfs.v5i1.1057

\section{Introduction}

Ulceris damage to both epithelium and lamina propria, and then a crater forms, sometimes the clinical finding are more obvious by oedema or proliferation causing swelling of the surrounding tissue. Sometimes ulcer is surrounded by a red inflammatory halo, usually around the yellow or grey ulcer.Most ulcers are due to local causes, such as trauma or burns. The term used to described these lesion is traumatic ulcers. ${ }^{1}$

Traumatic ulcers in oral cavity are relatively frequent and usually a result of mechanical injuries. Traumatic ulcers are usually found in non-keratinized surfaces such as cheek mucosa, edge of the tounge, and lips, and keratinized surfaces such as gingiva, hard and softpalatum. ${ }^{2}$

The treatment of traumatic ulcers given to the patients are medications such as variety of topical agents, antibiotics, anesthetics, antihistamines, nonsteroidal anti-inflammatory agents and enzymatic preparations. These treatment only used for symptom relief. These medication also made from chemical substances which have the side effects on human such as hypersensitivity or allergic and resistance to the medication. The efficacy of medications is uncertainly known as these agents have not been properly evaluated and only been used empirically. Therefore, an alternative medication is developed. ${ }^{2}$

The natural substances mostly used in medication are herbs. One of herbs can be found in Indonesia is cats tail plant (Acalypha hispida Burm. F.). Cats tail is known by society for its usage as a cure for some diseases such as white patches of skin (vitiligo), coughing up blood (hemoptysis), canker sores/ulcers, dysentery, and nosebleeds. In traditional healing, cats tail can be used for hemostatic medication, vitiligo, burn wounds, inflammatory bowel disease, threadworm infection (ascariasis), hemoptysis, wound healing, and diuretic. ${ }^{3}$

The phytochemical screening of both the ethanol and aqueous extracts of A. hispida leaves showed the finding of phenolic compounds, 
flavonoids, glycosides, steroids, phlobatanins, and hydroxyanthraquinones. $\mathrm{N}$-hexane extract of $\mathrm{A}$. hispida was known for containing alkaloid compounds, carbohydrates, phenols and alkaloids.

${ }^{4}$ Chemical compounds found in cats tail have medication effects, that are saponins, tannins, flavonoids, acalyphins, and essential oils that play a role as antibacterial.

Another phytochemical analysis showed cats tail indicated the presence of reducing sugars, saponins, cardiac glycosides, tannins, flavonoids, alkaloids, carbonyl group, terpenoids, and phlobatanins. ${ }^{5}$ Cats tail leaves has been reported to possess cytotoxic, antibacterial, antileprotic, antimicrobial, and antifungal properties. Bothethanol and aqueous extracts of A. hispida leaves significantly reduced the edema formation in carrageenan, as well as in histamine induced rat paw edema. This showed a significant anti-inflammatory activity of extracts. The cats tail leaves extracts also showed potent antioxidant activity. ${ }^{6}$

The objective of this study is to determine the effect of cats tail leaves extract (acalypha hispida burm. F.) on wound healing of wistar male rat mucosa (rattus norvegicus) and the result of this experimental which obtained later can be used as a reference in dentistry to develop cats tail leaves as an alternative medicine in traumatic ulcer treatment.

\section{Material and Methods}

This research type was true experimental laboratory with post-test only control group design. The study was conducted under the approval of Medical Ethical (398/H4.8.4.5.31/PP36-KOMETIK/2017) Faculty of Medicine, Hasanuddin University, Makassar, Indonesia.

This research was done at bio-pharmacy laboratory, faculty of pharmacy, Hasanuddin University. The experimental subject were 24 Wistar male rat divided into four treatment groups, including a $50 \%$ A. hispida leaves group, a $75 \%$ A. hispida leaves group, a $100 \%$ A. hispida leaves group, and povidone iodine control group. All rat in every group were given the treatment and the decrease of wound diameter were measured for 8 days then the data were processed using SPSS program.

Cats tail leaves were washed under the running water and drained so that the leaves were not too wet. The leaves then were dried using herbal dryer (oven) with the temperature of $50^{\circ} \mathrm{C}$. After the leaves dried, the extract were made through maceration method by soaked the dried leaves within $70 \%$ concentration of ethanol for 2 days. The ethanol were filtered using filtered paper and vapored using rotary evaporator until the viscous extract of A. hispida leaves were obtained. The extract were made into three concentration groups by dilution with NaCMC solution. The ratio of viscous extract and NaCMC solution is $1: 2$ for dilution with $50 \%$ concentration, $3: 4$ for dilution with $75 \%$ concentration, and 1:1 for dilution with $100 \%$ concentration.

Before the experiment was started, all the rats were adapted for 7 days in laboratory. After the adaptation, all rats were anesthetized by intramuscular injection of ketamil and then the traumatic injury with $5 \mathrm{~mm}$ diameter was made using needle holder. The treatment were given to all rats in every group once per day for 7 days and the wound diameter were measured for 8 days. The obtained data were processed using SPSS program.

\section{Results}

Table 1 showed the changes of wound diameter of all samples in every treatment group. The decreased of wound diameter also shown in the figure 1 below.

Table 2 showed the result of friedman test. The result showed the value of $p=0.000$, which means there is the significant wound diameter difference every observation day of all the samples in every treatment group.

Table 3 showed the significant increase of wound diameter changes between one day and another day in every treatment group $(\mathrm{p}<0.05)$, except the treatmet group with the value of $\mathrm{p}>0.05$. For example, the value of $\mathrm{p}=0.083$ between $3 \mathrm{rd}$ and 4th day in $50 \%$ A. hispida leaves group as well as the value of $p=0.102$ between 7 th and 8 th day.

Table 4 showed the insignificant difference of wound diameter between all treatment groups each day as the kruskall wallis test result showed the value of $p>0.05$, except on 8 th day with the value of $p=0.46(p<0.05)$. It means there is a significant wound diameter difference on that day.

Table 5 showed there is no significant difference of wound diameter changes betweenone treatment group and another group as the the value of $p>0.05$ which means the difference of wound healing effectiveness is insignificant. However, there are still the value of $p<0.05$ on 8 th day which means the significant difference of wound healing effect between one and another treatment group can be found that day.

\section{Discussion}

There is a significant wound diameter decrease in every treatment group. The most significant wound diameter decrease group is $100 \%$ A. hispida leaves 
Table 1 Differences of wound diameter in four groups based on obsevation in eight consecutive days

\begin{tabular}{|c|c|c|c|c|c|c|c|c|}
\hline $\begin{array}{l}\text { Treatment } \\
\text { Group }\end{array}$ & $\begin{array}{l}\text { 1st day } \\
\mathrm{x} \pm \mathrm{SD}\end{array}$ & $\begin{array}{c}\text { 2nd day } \\
x \pm S D\end{array}$ & $\begin{array}{l}\text { 3rd day } \\
x \pm S D\end{array}$ & $\begin{array}{c}\text { 4th day } \\
\mathrm{x} \pm \mathrm{SD}\end{array}$ & $\begin{array}{l}\text { 5th day } \\
\mathrm{x} \pm \text { SD }\end{array}$ & $\begin{array}{c}\text { 6th day } \\
x \pm S D\end{array}$ & $\begin{array}{c}\text { 7th day } \\
\mathrm{x} \pm \mathrm{SD}\end{array}$ & $\begin{array}{c}\text { 8th day } \\
x \pm S D\end{array}$ \\
\hline $\begin{array}{l}50 \% \text { A. hispida } \\
\text { leaves group }\end{array}$ & $5.00 \pm 0.00$ & $4.08 \pm 0.20$ & $3.42 \pm 0.58$ & $3.17 \pm 0.52$ & $2.75 \pm 0.76$ & $2.00 \pm 1.09$ & $0.75 \pm 0.88$ & $0.33 \pm 0.41$ \\
\hline $\begin{array}{l}75 \% \text { A. hispida } \\
\text { leaves group }\end{array}$ & $5.00 \pm 0.00$ & $4.25 \pm 0.27$ & $3.33 \pm 0.41$ & $2.50 \pm 1.27$ & $2.00 \pm 1.00$ & $1.58 \pm 0.80$ & $1.00 \pm 0.55$ & $0.50 \pm 0.45$ \\
\hline $\begin{array}{l}100 \% \text { A. hispida } \\
\text { leaves group }\end{array}$ & $5.00 \pm 0.00$ & $3.92 \pm 0.20$ & $2.83 \pm 0.41$ & $2.50 \pm 0.55$ & $2.50 \pm 0.55$ & $1.67 \pm 0.93$ & $0.75 \pm 0.52$ & $0.25 \pm 0.42$ \\
\hline $\begin{array}{l}\text { Povidone } \\
\text { iodinecontrol } \\
\text { group }\end{array}$ & $5.00 \pm 0.00$ & $4.33 \pm 0.52$ & $3.58 \pm 0.38$ & $3.25 \pm 0.42$ & $2.92 \pm 0.49$ & $2.42 \pm 0.49$ & $1.75 \pm 0.88$ & $1.17 \pm 0.61$ \\
\hline
\end{tabular}

Table 2 The differences of wound diameter between groups

\begin{tabular}{lcccc}
\hline Treatment Group & $\begin{array}{l}\text { 50\% A. hispida } \\
\text { leaves group }\end{array}$ & $\begin{array}{l}\text { 75\% A. hispida } \\
\text { leaves group }\end{array}$ & $\begin{array}{l}\mathbf{1 0 0 \%} \text { A. hispida } \\
\text { leaves group }\end{array}$ & $\begin{array}{l}\text { Povidone iodine } \\
\text { control group }\end{array}$ \\
\hline Wound diameter & 0.000 & 0.000 & 0.000 & 0.000
\end{tabular}

Friedman test, $\mathrm{p}<0.001$

\section{Table 3 Change of wound diameter for each day}

\begin{tabular}{|c|c|c|c|c|c|c|c|c|c|}
\hline Treatment Group & Day & 1 & 2 & 3 & 4 & 5 & 6 & 7 & 8 \\
\hline $\begin{array}{l}50 \% \text { A. hispida } \\
\text { leaves group }\end{array}$ & $\begin{array}{l}1 \\
2 \\
3 \\
4 \\
5 \\
6 \\
7 \\
8\end{array}$ & - & $\begin{array}{l}.020 \\
-\end{array}$ & $\begin{array}{l}.027 \\
.039 \\
-\end{array}$ & $\begin{array}{l}.026 \\
.034 \\
.083^{\star} \\
-\end{array}$ & $\begin{array}{l}.027 \\
.027 \\
.023 \\
.059 \\
-\end{array}$ & $\begin{array}{l}.026 \\
.026 \\
.026 \\
.024 \\
.024 \\
-\end{array}$ & $\begin{array}{l}.026 \\
.026 \\
.026 \\
.027 \\
.026 \\
.041 \\
-\end{array}$ & $\begin{array}{l}.026 \\
.024 \\
.026 \\
.026 \\
.027 \\
.039 \\
.102^{*} \\
-\end{array}$ \\
\hline $\begin{array}{l}75 \% \text { A. hispida } \\
\text { leaves group }\end{array}$ & $\begin{array}{l}1 \\
2 \\
3 \\
4 \\
5 \\
6 \\
7 \\
8\end{array}$ & - & $\begin{array}{l}.024 \\
-\end{array}$ & $\begin{array}{l}.026 \\
.026 \\
-\end{array}$ & $\begin{array}{l}.026 \\
.026 \\
.034 \\
-\end{array}$ & $\begin{array}{l}.024 \\
.026 \\
.026 \\
.034 \\
-\end{array}$ & $\begin{array}{l}.024 \\
.026 \\
.027 \\
.041 \\
.059^{\star} \\
-\end{array}$ & $\begin{array}{l}.026 \\
.027 \\
.027 \\
.042 \\
.039 \\
.038 \\
-\end{array}$ & $\begin{array}{l}.026 \\
.027 \\
.027 \\
.042 \\
.042 \\
.039 \\
.034 \\
-\end{array}$ \\
\hline $\begin{array}{l}100 \% \text { A. hispida } \\
\text { leaves group }\end{array}$ & $\begin{array}{l}1 \\
2 \\
3 \\
4 \\
5 \\
6 \\
7 \\
8\end{array}$ & - & $\begin{array}{l}.020 \\
-\end{array}$ & $\begin{array}{l}.026 \\
.026 \\
-\end{array}$ & $\begin{array}{l}.024 \\
.026 \\
.046 \\
-\end{array}$ & $\begin{array}{l}.027 \\
.027 \\
.041 \\
.059^{*} \\
-\end{array}$ & $\begin{array}{l}.027 \\
.027 \\
.024 \\
.024 \\
.083^{\star} \\
-\end{array}$ & $\begin{array}{l}.027 \\
.027 \\
.026 \\
.027 \\
.042 \\
.041 \\
-\end{array}$ & $\begin{array}{l}.024 \\
.023 \\
.026 \\
.026 \\
.043 \\
.042 \\
.0 .34 \\
-\end{array}$ \\
\hline $\begin{array}{l}\text { Povidone iodine } \\
\text { control group }\end{array}$ & $\begin{array}{l}1 \\
2 \\
3 \\
4\end{array}$ & - & $\begin{array}{l}.046 \\
-\end{array}$ & $\begin{array}{l}.026 \\
.024 \\
-\end{array}$ & $\begin{array}{l}.024 \\
.026 \\
.046 \\
-\end{array}$ & $\begin{array}{l}.024 \\
.026 \\
.023 \\
.046\end{array}$ & $\begin{array}{l}.024 \\
.026 \\
.023 \\
.023\end{array}$ & $\begin{array}{l}.024 \\
.026 \\
.024 \\
.026\end{array}$ & $\begin{array}{l}.024 \\
.027 \\
.026 \\
.020\end{array}$ \\
\hline
\end{tabular}




\begin{tabular}{lllll}
5 & - & .14 & .020 & .024 \\
6 & - & .0 .20 & .024 & .024 \\
7 & & - & .038 \\
& & - & - \\
\hline
\end{tabular}

Level of significance $\mathrm{p}<0.05 ; \mathrm{Cl} 95 \%$

${ }^{*} \mathrm{p}>0.05$ not significant

\section{Table 4 Differences of wound diameter}

\begin{tabular}{lrrrrrrrr}
\hline Day & $\mathbf{1}$ & $\mathbf{2}$ & $\mathbf{3}$ & $\mathbf{4}$ & $\mathbf{5}$ & $\mathbf{6}$ & $\mathbf{7}$ & $\mathbf{8}$ \\
\hline $\begin{array}{l}\text { Kurskal Wallis } \\
\text { test result }\end{array}$ & $1.000^{\star}$ & $.153^{\star}$ & $.070^{\star}$ & $.096^{\star}$ & $.0 .97^{\star}$ & $.160^{\star}$ & $.088^{\star}$ & \\
\hline
\end{tabular}

Level of significance $\mathrm{p}<0.05 ; \mathrm{Cl} 95 \%$

${ }^{*} \mathrm{p}>0.05$ not significant

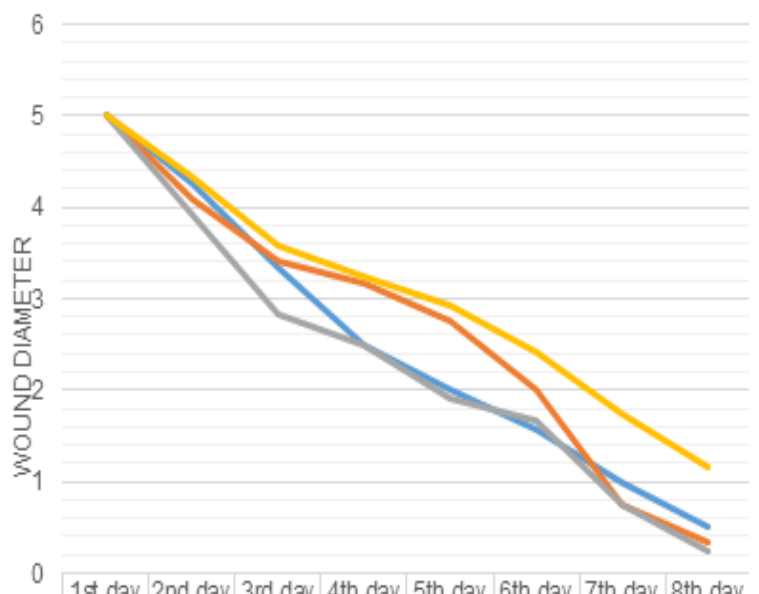

\begin{tabular}{|c|c|c|c|c|c|c|c|c|}
\hline & & & & & & & & \\
\hline $\begin{array}{l}75 \% \text { A. hispida leaves } \\
\text { group }\end{array}$ & 5 & 4,25 & 3,33 & 2,5 & 2 & 1,58 & 1 & 0,5 \\
\hline $\begin{array}{c}50 \% \text { A. hispida leaves } \\
\text { group }\end{array}$ & 5 & 4,08 & 3,42 & 3,17 & 2,75 & 2 & 0,75 & 0,33 \\
\hline $\begin{array}{c}100 \% \text { A. hispida leaves } \\
\text { group }\end{array}$ & 5 & 3,92 & 2,83 & 2,5 & 1,92 & 1,67 & 0,75 & 0,25 \\
\hline $\begin{array}{c}\text { Povidone iodine control } \\
\text { group }\end{array}$ & 5 & 4,33 & 3,58 & 3,25 & 2,92 & 2,42 & 1,75 & 1,17 \\
\hline
\end{tabular}

\section{Figure 1 Wound diameter mean graphic}

group, then $75 \% \mathrm{~A}$. hispida leaves group, then $50 \% \mathrm{~A}$. hispida leaves group, and last povidone iodinecontrol group. This shows that cats tail leaves have wound healing effect on traumatic injury. Anti-inflammatory and antioxidant activities of cats tail leaves in reducing the edema formation in carrageenan, as well as in histamine induced rat paw edema. The result showed cats tail leaves have significant anti-inflammatory activity. ${ }^{6}$

A. hispida leaves groups have the greater wound healing effect than povidone iodine control group due to the components which help in accelerating wound healing process found in A. hispida leaves, such as flavonoids, saponins, tannins, alkaloids, and essential oils that play the major roles as antibacterial, antioxidant, and anti-inflammation. Indicated the presence of flavonoids, alkaloids, saponins, and tannins in A. hispida after phytochemical analysis had been done. ${ }^{4,5}$ Another study that A. hispida contains saponins, tannins, flavonoids, acalyphins, and essential oils which could take a role as antibacterial. $^{5}$

Flavonoids are polyphenol compounds that play a role as antibacterial by forming complex compounds against extracellular proteins through hydrogen bonds that interrupt bacteria cell membrane integrity. ${ }^{78}$ Phenolic compounds as antibacterial can toxic the protoplasm, impair and penetrate cell wall, and precipitate microbe cell protein. The impairment of bacteria membrane cell inhibits the activities and biosynthesizes of specific enzymes required in metabolism reaction. ${ }^{9}$

Flavonoids as antioxidant can accelerate inflammation phase by pulling in that free radicals and restraining oxidation reaction with the increase of superoxide dismutase (SOD) and glutation transferase enzymes activities..$^{10}$ Flavonoids can inhibit inflammation mediators such as Interleukin-1 (IL-1) and tumor necrosis factor (TNF) produced by macrophage and cytokine receptor commonly characterized on the suppression of pain, fever, and tissues damage. Flavonoids also decreasing peroxide lipids, increasing epithelization quickness, and have antimicrobial property. The reduction of peroxide lipids by flavonoids will prevent necrosis, improve the vascularization, and repair the collagen fibers viability with the increasing of collagen fibers matting, and prohibit cell damage and improve DNA synthesis. ${ }^{11,12}$

lavonoids abilities as antioxidant and antiinflammation phenolic compounds exhibit several biologic activities such as antioxidant, anti- 
inflammation, anti-ageing, as well as inhibition of angiogenesis and cell proliferation. Most of these biologic activities have been associated with their intrinsic reducing capability towards prooxidants. On the other hand, biological functions of flavonoids include protection against allergies, inflammation, free radicals scavenging, microbes, ulcers, hepatoxins, viruses, and tumors. Phenolic compounds contained in A. hispida give the expected wound healing effect towards traumatic ulcer. $^{13}$

Saponins play the roles as antioxidant and antimicrobial, improving wound contraction and epithelization speed. Mechanism of saponins in wound healing is improving TGF- $\beta$ receptor ability as a growth factor needed by fibroblast in collagen synthesis. ${ }^{8,11}$ Saponins also have the ability as antiseptic with the function of killing the germs or prohibiting microorganisms growth on the wound in order to prevent serious infection.

Tannins also have the roles as antioxidant and antimicrobial, improving wound contraction and epithelization speed. ${ }^{11}$ Tannins can discontinue the exudates, slight bleeding, accelerate wound healing and mucosa membrane inflammation, and regenerate new tissues. ${ }^{712}$ On the other hand, annins also have antibacterial capability and the mechanisms are reaction with cell membranes, enzymes inactivation, and genetic materials functions inactivation or destruction.?

Alkaloids have the ability as antibacterial. The suspected mechanism is interrupting peptidoglycan compiler components in bacteria cell so that the cell wall layers are not fully formed and causing the death cell. ${ }^{7}$

Essential oils contain phenols and chavicol useful as antimicrobial, antibacterial, and desinfectant. These content can clean the wound and prevent the infection in order to accelerate the end of inflammation phase on wound healing process. ${ }^{12}$

The decreased of wound diameter also takes place in povidone iodine control group can be caused by antiseptic capability of povidone iodine which is good for wound treatment. Povidone iodine can kill bacterias, both positive gram bacterias and negative gram bacterias. ${ }^{14}$

\section{Conclusion}

Cats tail leaves extract (acalypha hispida burm. F.) with concentration of $50 \%, 75 \%$, and $100 \%$ have the effect of wound healing on traumatic injury of white rat oral mucosa (rattus novergicus) but there is no significant difference in effectiveness between every concentration.

\section{Acknowledgment}

We would like to appreciate the faculty of Dentistry Hasanuddin University for their support to this study.

\section{Conflict of Interest}

The authors report no conflict of interest.

\section{References}

1. Scully C. Oral \& maxillofacial medicine: the basis of diagnosis and treatment. 3rd ed. Churchill Livingstone: Elsevier; 2013. p. 154.

2. Cavalcante GM, Paula RJSd, Souza LPd, et al. Experimental model of traumatic ulcer in the cheek mucosa of rats. Acta Cir Bras 2011;26: 227-234

3. Moningka KC, Kojong NS, Sudewi S. Antibacterial activity test of cat tail (Acalypha hispida Burm. F.) leaf extract against staphylococcus aureus and Escherichia coli bacteria in vitro. Pharmacon J Ilmiah Farmasi 2015;4: 193-202. (In Indonesia)

4. Febriyanti M, Sanjaya BW, Supriyatma, et al. Antioxidant activity of ethanol extract and fractions of cat tail leaves (Acalypha hispida Burm. F.) by the method of inhibiting the reduction of water soluble tetrazolium salt-1 (WST-1). Fitofarmaka 2013;3: . (In Indonesia)

5. Osarumwense PO, Okunrobo LO. Phytochemical screening and the antimicrobial properties of Acalypha hispida Burm. F. (Euphorbiaceae). AJOPRED 2013;5: 36-39.

6. Siraj MA. Anti-inflammatory and antioxidant activity of acalypha hispida leaf and analysis of its major bioactive polyphenols by HPLC. Adv Pharm Bull 2016;6: 275-283.

7. Wijaya BA, Citraningtyas G, Wehantouw F. Potential of ethanol extract of taro leaf stalk (colocasia esculenta [L]) as an alternative medicine for wound on rabbit skin (Oryctolagus cuniculus). Pharmacon J Ilmiah Farmasi 2014;3: 211-219. (In Indonesia)

8. Ruswanti EO, Cholil, Sukmana BI. The effectiveness of etaya extract of papaya leaves (carica papaya) $100 \%$ of wound healing time. Dentino J Kedok Gigi 2014;2: 162-166. (In Indonesia)

9. Sumoza NS, Efrizal, Rahayu R. Effect of gambier (Uncaria gambir R.) on the healing of burns in male white mice (Mus musculus L.). J Bio UA 2014;3: 283-288. (In Indonesia)

10. Fuadi MI, Elfiah U, Misnawi. The number of fibroblasts in second-degree burns in rats by giving ethanol extract gel of cocoa beans and silver sulfadiazine. eJPK 2015;3: 244-248. (In Indonesia)

11. Rupina W, Trianto HF, Fitrianingrum I. Effect of $70 \%$ ethanol extract ointment on caramunting leaves on reepithelialization of wistar rat skin incision wounds. eJKI 2016;4: 26-30. (In Indonesia)

12. Kusumawardhani AD, Kalsum U, Rini IS. Effect of betel leaf extract ointment (piper betle Linn.) on the number of fibroblasts of degree IIA burns in white rats (rattus novergicus) wistar strain. Majalah Kesehatan FKUB 2015;2: 16-28. (In Indonesia)

13. Onocha PA, Oloyede GK, Afolabi QO. Phytochemical investigation, cytotoxicity and free radical scavenging activities of non-polar fractions of acalypha hispida (leaves and twigs). EXCLI J 2011;10: 1-8. 
14. Putri NT, Sarianoferni, Wahjuningsih E. The effect of low LET (Linear Energy Transfer) ionizing radiation to catalase activity of wistar's submandibular gland. J Dentomaxillofac Sci 2016;1: 145-149.

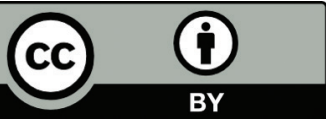

This work is licensed under a Creative Commons Attribution 